\title{
16 Encoding the law of the household and the standardisation of uncertainty
}

\author{
Angela Mitropoulos
}

\begin{abstract}
Maps
All maps involve subtractions from complexity - a condition that is both crucial for readability and, at the same time, a procedure that tends toward essentialism and obsolescence. Moreover, maps were, and are, anticipatory. If not quite the performance, then the script. According to J. B. Harley's notations in the margins of cartographic history, 'lands [were] claimed on paper before they were effectively occupied'. That is, 'maps anticipated empire. Surveyors marched alongside soldiers, initially mapping for reconnaissance, then for general information, and eventually as a tool of pacification, civilisation, and exploitation in the defined colonies' (2001: 57). As logical systems, maps are therefore not so much representational artefacts as propositions (Wood 2010: 41). This is especially so where mapping links laws and objects by encoding the defined properties of the latter in such a way that they are amenable to normative statements. This is why the history of the map is also the history of the concept of precariousness. The foundational incertitude of property rights is the protean circumstance that connects these two histories at the methodological juncture between property law and normative claims inferred from an assured knowledge about the enduring, unique properties of stuff. From imperial maps to cadastral records, the classical and modern cartographic ambition was to brush aside the irritant of epistemic uncertainty, to subtract from the semantic ephemera of (as Aristotle called them) accidents and anomalies, and in so doing to furnish a navigable and familiar habitus of scientific knowledge that was, at the same time, the construction of an intimate familiarity by way of mundane connections between 'the illusion of realistic and objective space' and the aesthetics of the intimate, habitable space of the home (Smith 2008: 62; Bachelard 1994). As Korzybski writes, 'the map is not the territory' (Korzybski 2000: xvii).

Herein lies the social cartographic significance of the concepts of précarité and precariousness. The somewhat paradoxical certainty that these concepts represent an unscripted truth disconnected from its provenance in government policy and statistics forgets that they arose from the faltering of two, crucial technical assumptions of statistical procedures and policy: the mathematical construction of a universal space of equivalence that makes comparability and ranking possible
\end{abstract}


(Desrosières 1998), and its capacity to yield propositions about stuff with some plausible modicum of rhetorical-scientific force. Together these describe the procedures upon which a claim for (social scientific) objectivity had been staked and from which it drew normative implications for government policy. For much of the nineteenth- and twentieth-centuries, these techniques preserved a methodological nationalism that scaled up from the familial household and scaled across as (national) populations, furnishing the enumeration of law-like regularities that converted propositional statements about the unique, enduring properties of classes and entities into persuasive rules and norms built on the expectation of a predictable future. They also enacted the rule-based procedural line that personifies and connects taxonomic ranks (such as family and nation), elaborated as the possession and transmission of unique, heritable properties, or essences) - which is to say oikonomia, or the (nomos) law of the (oikos) household.

While the concept of precariousness has not always been an explicit feature of policy, laws or statistical research, its reach has nevertheless been implicit in the 2009 standards issued by a group concerned with the universal engineering standards of organisations and systems. The concept of 'uncertainty' has had a much longer conceptual history in economics and the (physical) sciences than 'precariousness' has had in philosophy, sociology and the humanities, though 'uncertainty' is also codified within ISO 31000, where it is defined as 'an environment full of uncertainty' (International Organization for Standardization 2009). The ISO 31000:2009 was based on the AS/NZS ISO 31000:2004 issued by Standards Australia in 2004, at the same time as 'casualisation' or zero-hour contracts had become not the exception but the standard wage contract (Mitropoulos 2005). Notably, the ISO insists that its acronym follows the French version of its name because 'ISO' recalls Plato's esteem for isometric forms. The purpose of the ISO's codification of 'uncertainty' is that it regulates accounting control systems whose aim it is to identify, measure, manage and - given the integration of actuarial practices - price risk, so as to optimise performance and maximise monetary returns. Risk, contra Ulrich Beck (1992), is not here understood as simply downside risk, but the analytical determination of a ratio, of more or less elaborate correlations, between possible gains and losses (Mitropoulos 2015). While some disciplines and researchers have used either 'precariousness' or 'uncertainty', for many and in the early literature they are often used interchangeably - this is not to say there are no differences, but it does suggest an epistemological orientation and research platform across disciplines.

Presented as the simple description of an existential truth and not as an overt system of accounting, the concept of precariousness - as Gaston Bachelard suggested of the figural, fragile nest - suggestively 'set us to dreaming of security'. When we dream, he went on to add, 'we are phenomenologists without realizing it', and 'in the very impetus of the imagination - we return to the sources of the oneiric house' (Bachelard 1994: 102-3). Of course, one person's nest is oftentimes another's place of work (Aguiar and Herod 2006; Mullally 2015) or, with some statistical regularity, is the scene not of repose but of intimate violence (Pleck 2004; Kelly 2003). Indeed, for some time now, the speculative inclination 


\section{Angela Mitropoulos}

of national security doctrine and the imperative urge toward the remedial regulation of a phenomenal fragility have blended and forged a routine, hyperbolic violence around the sequential conflations of family, race and nation. This is the sense in which the inclination of 'precarity', as precor, shifts so easily toward 'praying for guarantees and, at times, shields that often turn out to be fortresses' (Mitropoulos 2005).

\section{Précarité and precariousness}

In the early 1980s, French Government statisticians began using the category of précarité in labour force surveys (Barbier 2002; French Ministry of Labour 1992). That history was preceded by its use in studies of rural-to-urban migration and Agnès Pitrou's ethnographic studies of les solidarités familiales (1978, 1992). Research such as that undertaken by Josef Gugler on labour migration in Sub-Saharan Africa is indicative of the ways in which 'precarious' had come to describe not the 'precarious (property) title' referred to in the earliest codification of civil law in the first century (Scott 1973), but the porosity and scattering of the boundaries of a disciplinary object from whose regularities (policy) norms were conventionally derived - or, as Gugler put it, such a study would 'provide excellent data for answering central sociological questions such as: How do changing economic forces and social norms interact?' (Gugler 1968: 463). Over later decades, the concept of précarité would become the phenomenological description of an existential condition, having slipped its relegation to the margins of sociological objectivity. In reconsidering this history and its implications, this chapter extends and modifies two arguments made elsewhere: that 'precarity' pertains to the dynamics and displacement of a specifically capitalist uncertainty (Mitropoulos 2005); and that contemporary welfare, social and economic policy treats contingency as (capitalist) necessity, whose policy implications are more or less explicitly shaped according to an oikonomia (law of the household) construed as the necessary, dispositional fundament of capitalist futurity (Mitropoulos 2012).

Overall, this chapter theorises the link between the phenomenological concept of precariousness and the statistical category of précarité in the context of a broader, partial turn to theories of 'spontaneous order'. It does so by critically reading Hayekian theories of 'spontaneous order' not as arguments for deregulation but, on the contrary, as normative claims for the endogenous regulation of uncertainty by means of encoding rules of selective conservation. Those rules pertain to methods for handling 'life' according to universal standards and the managerial gain of 'investment' in categorical forms (Thévenot 2009), and investment in categorical forms is weighted in policy and scripted through rules so as to guide the strategic calculations of risk-bearing subjects. This has entailed a renewed emphasis on a phenomenological 'parts-whole' paradigm. It is a reformulated epistemology that reluctantly admits the inferential weaknesses of macro-scaled, probabilistic distributions and categorical 'incompleteness'. Yet whether it does so to salvage a metaphysics of forms from the incapacitation of 
normative inferences and prediction, or because the total elimination of anomaly does away with scientific and creative invention, is an arguable point. It depends to some extent on whether the reconstruction of a framework follows invention. Inasmuch as it does, the recourse to local-scaled ethnographic knowledge of the non-correspondence between universal standards and forms, the creative fuzziness that aesthetic imagination contributes by stretching probabilities into a modal range of possibilities, or the simplification of complexity by clustering data sets is perhaps far less indicative of a jump into a different eigenstate than the reformation up of 'parts-whole' Platonism along the way.

In the case of the statistical category of précarité, the argument here is that it involved a shift from statistical measures of national labour capacity to a metrics of uncertainty based on Pitrou's indicators of risk absorption and the cost of inter-generational transactions (solidarités familiales), along with the statistical clustering of non-uniform contract durations undertaken by government statisticians at the government's statistical bureau. The informational yield of these indices is not the national unemployment rate or Gross Domestic Product (GDP) as it was in earlier research on the rate of unemployment but, first, the feasibility and cost of transferring risk from governments and corporations to households and, secondly, the ratio of risk (flexibility-disorder) in the system. It is the ratio (of the ratio) between flexibility and disorder that furnishes a new metrics of social volatility. As Dirac claims: 'a measurement always causes the system to jump into an eigenstate of the dynamical variable that is being measured' (Dirac 2004: 36).

These metrics signal the abandonment of the premise that the wage corresponds to a quantum of labour and instead underline the role of the contract as a mechanism for the allocation of risk (Mitropoulos 2012, 2015). For instance, in André Masson's modelling of precarious work, labour is not measured as a stock of energy (a 'lump of labour') but as the 'virtual risk' contained in a 'demographic flows-stock' system (1983: 28). Such arguments follow the trend from classical to modern physics in successive understandings of the properties of energy - from the elemental phlogiston, through Antoine Lavoisier's substances, to kinetic energy (statistical distribution and error rates), and on to the energetic vortices of quantum physics. This parallels a shift in concepts of labour: from labour as formgiving fire, to a substance, to a focus on the ratio of employment to unemployment as a statistical measure of entropy (i.e. as the statistical rate of the unavailability of energy for conversion into 'useful work'), to a current emphasis on measuring the degree of disorder or randomness in the system. The difference between the metrics of GDP and those set to marking degrees of randomness or disorder is not as subtle as it might seem.

While the push to predictability was integral to the early use of statistics in policy, it could not account for stochastic processes that troubled categorical neatness and, at the same time, implied the destruction of entrepreneurial risk: for early neoclassical economists such as Frank H. Knight, the unbounded elimination of uncertainty would mean the elimination of above-average profits and losses, the mythic quality of entrepreneurialism (Knight 2006; Mitropoulos 


\section{Angela Mitropoulos}

2015). Furthermore, an emphasis on the degree of disorder and not entropy sets aside the substantive distinctions and polarities of 'the reserve army of labour' and 'full employment', so as to both uphold the personalised, customisable tenets of human capital theory and put the category of unemployment to work. Significantly, this supersedes Michał Kalecki's contention - which drew upon Rosa Luxemburg's theory of capitalist dynamics (2004) - that 'full employment' would be corrosive of discipline in a labour market but feasible under conditions of involuntary or forced labour (Kalecki 1971). Workfare, zero-hour contracts and below-subsistence wages blur the categorical distinctions between employment and unemployment (as well as employer and welfare agency, welfare recipients and the working poor). Importantly, they do this while maintaining a high degree of discipline.

For management, however, there is a downside risk of maintaining discipline through intermittence and related measures of 'flexibility', namely disorder. This is why it is important to emphasise a proportional concept of risk. Risk management is a consideration of this ratio (Mitropoulos 2015). It is notable that, in both Pierre Bourdieu's and Richard Sennett's ethnographic studies of younger workers (the first discusses 'précarité' and the second downside 'risk'), disorder is presented as a lack of attachment of workers to employers, a prospect that Bourdieu and Sennett present as a matter of grave concern for maintaining social cohesion in the face of 'globalisation' and, in Sennett's account, a degeneration of the normative character traits of loyalty and trust (Bourdieu 1993; Sennett 1999).

In actuarial-fiscal terms, welfare policy and social insurance are questions about which (and whose) transaction costs (or contracts) should be underwritten, the means by which the risks of contracting are pooled, spread, and priced. The institutional setting of these calculations are generic combinations of government, non-government and corporate systems, including those of welfare, such as in the case of pension funds (Clark 2000), the financial instruments of social investment schemes (Mitropoulos and Bryan 2015), and the practices of punishing (non-corporate) welfare recipients for transgressions of behavioural codes of conduct set by joint public-private agencies (Stoesz 1999). Caution is required when using privatisation rather than risk management as the lens through which to understand these changes. It makes sense to talk of privatisation to describe the transfer of risk from government to households in one regard, particularly insofar as it can entail the reduction of transaction costs by calling upon unpaid labour in the home. Yet the sweeping juxtaposition of states and markets is an insufficient guide for considering the history and current terms of welfare and other policy, not least because it neglects the ways in which laws, codes, contracts and universal standards (including money as a universal equivalent) have always linked and shaped any salient differences along those lines. The concept of privatisation can often neglect the crucial difference between strategies which decrease transactional costs by calling upon unpaid labour, as in Becker's human capital theory and New Household Economics (1962), and those which transfer revenue to corporations to carry out compliance or risk-shifting, as in outsourcing. 


\section{The precarious form of value}

The form of value (or value-form) of the classical scientific paradigm - that is, the valid form of reasoning that infers norms or rules (or what is right and proper) from the common properties of classes - has been supplanted by an emphasis on the endogenous regulation of properties through selective conservation, or in other words, the evaluative rules of self-regulatory systems based on the conservation of unique properties and their patterned advance. This entails an emphasis on mechanisms of risk-shifting and selective conservation, where the attachment to categorical forms is recast as the strategic calculations of risk-bearing subjects. In practice, the risk of some transaction costs are underwritten, others are not. This is the terrain of post-welfare social management theory, setting the protocols to guide and underwrite decisions as investments in human capital and households, and to do so where the meaning of decision itself is rendered precarious according to the patterning of legal protections (Mitropoulos 2016).

The blows to the classical paradigm delivered by Kurt Gödel's theory of the undecidability of forms illustrates the extent to which this was an epistemological, mathematical problem within the categorical certitude of statistical methods, even though those blows would not have landed as they did without a range of struggles that Gilles Deleuze and Félix Guattari described as the 'flight from the enclosures' (see Deleuze and Guattari 1988). Gödelian 'undecidability' means, briefly put, that the inclusion of statements of a system's consistency within that system makes that system inconsistent (Gödel 1962). The implication is that any language or formal semantic system which involves mathematics, syntactical formulae of classes, ranking and number or computations is 'incomplete'. The insight of Gödel's mathematical theorem of formal undecidability is, in this chapter, extended to suggest that systems of classification cannot include an account of the validity of their predicates without breaking down and, subsequently, responding to that breakdown by resorting to metaphysics (such as universal standards) so as to stake an a priori claim on categorical necessity (as Gödel himself did). Alternately, they are compelled to reach beyond syntax to context and thereby to non-necessary (historical) explanations of categorical forms and their methods (as the approach in this chapter does). The point is that the concept of precariousness identifies and transfers the risks of deciding on what (in the Gödelian sense) is 'undecidable' - a procedure that among other things reconstructs decision as a matter of attachment to and selective conservation of categorical forms or, as Laurent Thévenot would say, the 'investment in forms' (Thévenot 1984).

\section{Spontaneous orders and selective conservation}

The assumptions behind the concept of 'spontaneous order' are often obscured by, on the one hand, its associations with one side of Cold War polemics over 'free trade versus state planning' (Hayek 1960) and, on the other hand, the eclipse of earlier polemics within Marxism over 'spontaneous organisation' (Luxemburg 2006; Lenin 1902). This has obscured the meaning of positions taken on 


\section{Angela Mitropoulos}

calculative reason. Despite the usual reading of the first set of arguments, Friedrich Hayek's argument for 'liberty of contract' followed the Spanish Scholastics, from whom concepts of contract freedom and the ius communes (the just distribution of the common good) were borrowed. Moreover, despite their differences, both Hayek and Karl Polanyi dispensed with 'freedom of contract' at the front door of the familial household and at the edge of presumably archaic tradition. For the Spanish Scholastics, freedom of contract found its limit-case in the proper, categorical orders of oikonomia (the law of the household), and the ius communes took its form of 'right reasoning about properties' from a natural law understanding of the oikos (Schermaier 2009). In Hayek's terms, this is pattern recognition and pattern prediction (1994). Unlike Hayek, Luxemburg, trained in mathematics and statistics, treated (statistical) patterns as the operational effects of a methodological apparatus and its metrics and not as naturally occurring forms of providential design. Indeed, Luxemburg put forward a theory of the spontaneous emergence of order and dynamic complexity well before Hayek (Mitropoulos 2016). It is also worth recalling that the so-called Socialist Calculation Debates, which raged between those influenced by Luxemburg and Hayek's predecessors, understood calculation as a debate about the political regularities of economic processes and the extent to which the state (or polis) could or should regulate economics (oikos). Those debates involved a range of positions, including Oskar Lange's socialist arguments for state planning as 'programming under conditions of uncertainty' (1971: $\mathrm{x}$ ).

That said, theories of 'spontaneous order' derived from Hayek involve, first, an argument for the endogenous regulation of properties through selective conservation (or qualification), and second, an argument that the circumstances in which this occurs are (paradoxically) necessarily uncertain. Put in more classical Scholastic terms, this implies that contingency is necessity (Mitropoulos 2012: 27-9). In more contemporary, Hayekian-derived terms, this implies a theory of selective conservation in the face of inevitable uncertainty. A 1991 working paper from the Santa Fe Institute defined it in this way:

This new body of thought implies that the poised coherence, precarious, subject to avalanches of change, of our biological and social world is inevitable. Such systems, poised on the edge of chaos, are the natural talisman of the adaptive order.

(Kauffman 1991: 2)

This is not the subordination of qualities by quantification that is so often decried in ongoing, neo-Kantian conflicts between the faculties of the humanities and the sciences - an assumption that continues to shape understandings of neoliberalism as deregulatory and preoccupied in the main with the subordination of political, moral and ethical values by 'economic calculation' (Brown 2005: 46).

From the angle of Hayekian spontaneous order, the question posed by these concepts of welfare policy is not one of evolutionary biology ('How do things change?') but, on the contrary, 'How does capitalism undergo changes while 
staying the same?' In Aristotelian logic, this is called the problem of entelechy. Where selective conservation diverges from the evolutionary (Darwinian) theory of 'natural selection' is in the emphasis the former accords to the preservation of the ostensibly regular properties of uniquely existing entities. For Charles Darwin, by contrast, the encounter between transmissible variations and uncertainty is the non-teleological condition of adaptation. The point is not that Darwin's theory is without its problems, even less socio-biology, which amounts to the recapture of Darwinian evolution by Aristotelian teleology. It is that the Darwinian theory of evolution is the inverse of Pitrou's argument that 'family solidarity' acts as a shock absorber in dealing with happenstance $(1978,1992)$. In other words, it is instructive that the proposition of an 'environment full of uncertainty' precipitates an argument for the preservation and solidification of ostensibly universal forms and not for, say, the diversification that in Darwinian theories of evolution increases the range of chances and possible futures. The emphasis on shock-absorption is moreover the source of later concepts of 'resilience', and in this sense less biopolitical in its 'politicisation of life' than it is oikonomic in its conflation of national security doctrine with the financial securitisation of the household.

Moreover, Pitrou's concept of familial solidarity, and its corollary focus on inter-generational solidarity and population policy were used with increasing frequency by conservatives in France precisely because of how they diverged from Darwinian concepts of non-teleological evolution and adaptation. Indeed, by 1999 the Juppé Government had established a Ministry for Solidarity Between Generations. There is a similar conjuncture between the concept of 'fragile families' (Kowaleski-Jones and Wolfinger 2007) and conservative welfare policy elsewhere. This is because these concepts pose a question about the transactional costs of such things as pension schemes, aged care - as questions about the flows of insecure migrant care workers and/or the 'gift economy' of family solidarity because they are concerned with the selective preservation of categorical properties rather than the variability that is integral to adaptation. This is not quite the 'partswhole' neo-Platonism of G. W. F. Hegel or Edmund Husserl, though it travels in both their shadows. Instead, the training of statisticians places an increasing emphasis on the default, conventionalist Platonism of social and political engineers seeking to encode a link between ideal and phenomenal forms of life through universal standards (or laws). The implications it holds for the transfer of risk from corporations to households are immense, as noted by the International Monetary Fund's 2005 Global Financial Stability Report, which observed that 'the household sector has increasingly and more directly become the "shock absorber of last resort" in the financial system' (IMF 2005: 5).

\section{Regulating precarious life and universal standards}

The recurrent syntactical use of an adjective (précarité, precarious) as a concept underlines its status as an operating function within a larger formulation. Cutting across this, the entwined histories of sociology and property law are crucial reminders that the systematic use of grammatical operators involves a history. On 
the one hand, the emergence of the classical sociological paradigm (of Auguste Comte, Adolphe Quetelet, Emile Durkheim, Max Weber) occurs at those moments where the unique coherence of its object - society - is deemed to be at risk of being rent asunder by divisions and, at the same time, to be a necessary and natural whole whose contours just happen to accord with those of nation-states (Mitropoulos 1999). On the other hand, the earliest effort at legal codification the Byzantine Empire's compendium of civil laws (Scott 1973) - is replete with mentions of 'precarious title' over land and slaves. The dropping of the explicit referential (to property title) points toward the Early Modern Lockean redefinition of contractual personhood as 'property-in-one's-self' (Macpherson 1983) and, furthermore, underscores the sense in which the demand for (property) rights are often couched in somewhat Byzantine terms as the restoration of a lost empire.

The link between norm or law and systems for classifying the properties of things is crucial. Firstly, the use of these concepts suggests an effort to reorient social-scientific conventions from the mapping of known probabilities to a cartography of the 'non-standard', anomalous or stochastic. This accords with the trajectory from classical to neoclassical paradigms in the natural and physical sciences, not least since Thomas Kuhn pointed out that scientific invention turns on the assimilation of that which was previously deemed as being anomalous or accidental (1970). Indeed, without exploiting this frontier of the anomalous or stochastic (and in contemporary terms, 'the household frontier') by translating it into universal, categorical forms, the machinery of universal equivalence and classification comes to a tautological, non-generative standstill. As in Marx's depiction of the circuit of capital, without this exploitation, ' $\mathrm{C}$ does not become $\mathrm{C}$ '.

Secondly, the concepts of précarité and precariousness describe again the familiar habitus of (national) statistical space in emphatically aesthetic terms. Prediction comes to rely more on imagined scenarios, speculative estimates, qualitative ethnography and fuzzy categories than on the extensive enumeration of past frequencies into the future. Where neoclassical economics multiplied objective probabilities by way of the concept of preference, so too phenomenology and associated ethnographic studies shifted the emphasis from known probabilities to the range of all that can be imagined and is possible, often at lower scales. Scenario planning and game theory, for instance, incorporate aesthetic and phenomenal possibilities into tools of statistical modelling. Statistics responds to the challenge of randomness by scaling-down, clustering, or plotting the relationship between the 'poised coherence' of categories and Hilbert space so as to model intergenerational household assets in systems whose borders are porous. In the reorganisation of the faculties as a division of labour between the conscription of researchers and the use of an implicit methodological script, phenomenology can function just as well through the aesthetic, roughly encoded and local-scaled part of this 'parts-whole' methodology as it can fuel a philosophical firewall against the corrosive implications of categorical undecidability.

Thus the epistemological assumption of a 'parts-whole' relationship between objects readily converts variety into a Platonist question about an entity's 'participation' in universal, eternal forms. Judith Butler's discussion of 'precarious 
life', wherein 'open-ended and plural cohabitation' is framed as a species of 'global ethics' is an elegant case in point (2012: 144). Where classical statistics frowned upon 'deviations from the average' (as in Comte), in contemporary phenomenology, after a brief ethnographic detour through the margins, those 'deviations' are translated back into universal law as an approximate case. Similarly, the debate between Erin Manning and Jodie McNeilly over whether bodily movements outrun the metastable, precarious equilibria of subjectivity is a debate between processual and phenomenological paradigms of variation, one that underscores the theological affiliations of the latter (Manning 2014; McNeilly 2014). This echoes previous debates about the ways in which the concept of precarity sought to enjoin a faltering movement to the task of reconstructing a measure of a general rule (Mitropoulos 2005). Phenomenology, of course, involves a more or less tacit question about eternal Being's appearance in, by its view, the messy sensorium (Hegel 1977; Husserl 1970; Janicaud 2000). In the phenomenological view, nothing 'of substance' changes, except the modes, which as modes of a metaphysical substance are conceived as amenable to measure and comparability. And "unruly specificities" - to borrow a phrase (Law 2009: 8) are thereby treated, at best, as either modal multiplications of this metaphysical whole, or as an index of divergences from ideal forms (of labour, polity, community, nation and so on) whose existence, as uniquely existing entities, is routinely given in languages, rhetoric and histories as an idea, but always falls short in any attempt at empirical verification. This is a strict philosophical idealism in that its impetus is to convert ostensibly unformed matter into ideal forms. In this way, the implicit question is much like - and often simply just is - the classical theological concern with the preservation or dissolution of the immortal soul (Elkaisy-Friemuth and Dillon 2009), and universal standards and codes are the abstract scripture which guides the risk-bearing subject's prudential reckonings or risk-taking calculations of transactional costs. The propositional yield of arithmetic-phenomenological co-operation are codes of conduct in which regulation (or conformity to a rule) means the operationalisation of the formal rules of semantic systems that are framed by the vital qualifying point of ostensibly eternal and uniquely existing forms or, in more explicitly vitalist accounts, by the ideal form of life encompassing all forms. That is, up to the ranking qualifications (the borders) of the categorical forms of 'species-genus' reasoning that recalls Aristotle and Carl Linnaeus far more than Darwinian a-teleological, evolutionary time or Donna Haraway's recombinant, a-categorical speciation.

Thévenot's argument in Governing Life by Standards and elsewhere, by which he meant 'the deployment of standards throughout our lives and the lives of all living entities' (2009: 793), is an argument made in close proximity to the development of the concept of précarité. At the beginning of the 1980s, government statisticians at the Institut National de la Statistique et des Études Économiques (INSEE) began discussing modifications to the statistical classes used in national surveys of the labour force (Eymard-Duvernay 1981: 68). From the late 1970s, the INSEE had taken a robust interest in exploring the history of statistical axioms beyond the usual administrative questions of operationalisation 
and interpretation. While politically diverse in some respects, most of its staff had been trained at the École Nationale de la Statistique et de l'Administration Économique (ENSAE). Michel Aglietta, who would come to be associated with the post-Marxist Regulation School, studied at the ENSAE and worked at the INSEE for some time (1964-75). Bourdieu, who positioned himself within the libertarian tradition of the Left, taught at the ENSAE briefly between 1963 and 1966. While the regulationist approach emphasised regularities at different scales, Bourdieu's cultural sociology took its cues from Ruth Benedict's cultural anthropology, wherein each individual is a fractal, scalar instance of a larger-scale culture that, in turn, is both figuratively personified and understood as having a personality. These more or less isometric, scalable 'parts-whole' constructions reflect a statistical training and concept of properties. Yet unlike in Benedict's argument, where she contended that it was possible to infer from a comparison of 'primitive' cases what is 'specific to local cultural types and those that are general to mankind' (1934: 20), in late 1960s France, this 'parts-whole' edifice was reconstructed from both angles: by way of localised ethnographic research, often about young workers (Bourdieu 1993), and the propositional certainties of universal standards (Thévenot 2009). Categories became clusters, informed on the one hand by qualitative, ethnographic research and, on the other, accorded the weight of validity in policy terms through the rule-based formalism of the conventionalist approach.

The conventionalist approaches of Thévenot and Luc Boltanski came to the fore in the early 1980s, often in sharp contrast to Bourdieu's cultural sociology, which placed the emphasis on political norms, and still further from Marxism. They were also reminiscent of earlier influences on the ENSAE, including a concern with the engineering of standards and the codification of 'life' (Thévenot 2009, 1983a, 1983b). The emphasis on reflexivity and convention in this approach created a link between understanding the historical limits, imprecision and artifice of particular techniques and applying them nevertheless. The conventionalist approach at the ENSAE could, then, be viewed as a moving bridge between the pragmatic Platonism of mathematicians (for whom the axioms and techniques through which statistical space is constructed are based on theorems, subject to dispute, reformulation and experiment) and the pragmatic realism of the statistical professions (for whom the construction is an occupational necessity).

From the late 1970s there was, as Bernard Mériaux put it, 'a specific question [posed] regarding the reasons and above all forms of [employment] segmentation in the French case, inspiring several research programs, frequently across axes exploring the variety of forms of precarious employment' (1978: 133). Mériaux cites Michael Piore (visiting from MIT), whose theory and study of labour market segmentation in France - that is, a growing gap between stable, well-paid jobs and a secondary 'sector ... manned by women, youth, minority groups, migrants, parttime peasants and other groups which we tend to think of as marginal or "disadvantaged" - appeared in the same 1978 edition of Revue Économique (1978). Piore makes no mention of precariousness, though the essay is subtitled 'A Response to Uncertainty and Flux'. From the late 1970s, statistical surveys 
increasingly classified the labour market through the explicit criteria of contracts: formes particulières d'emploi (FPEs) and contrats à durée indéterminée (indefinite contracts). This new nomenclature was used in an increasing number of statistical surveys and outlined in the 1979 Report of the Planning Commission (Michon and Germe 1979; Barbier 2002: 7). Within a decade, the non-standard work contracts which had been statistically aggregated as FPEs were redefined as statuts précaires in labour force surveys from as early as 1982, as situations précaires in statistical tables, and subsequently as précarité in the Labour Code, in the minimum income (RMI) law of 1988, and across all government and administrative departments (Barbier 2002). The FPE clustered data on temporary agency work, apprenticeships, seasonal work and short-term contracts together with housework and aidex familiaux (work undertaken for a familial relative whose data was enumerated in another class, i.e. as self-employed).

In the history of statistics and particularly its computations, the practice of clustering arose as a means to combine entities deemed to be not of the same property but of approximate resemblance (Ammar et al. 2015), or: more like than unlike, rather than the same. Cluster analysis involves the explicit use of logical steps (algorithms), and is often used in machine learning, pattern recognition and information retrieval systems. It is one of the most prevalent tools of social scientific research on precariousness (e.g., O'Rand 2011; Scherer 2001; Muntaner et al. 2012; Herman 2014; Verd and López-Andreu 2012). Yet while clustering enhances the complex view of multivariate data, without the superposition of a qualitative hierarchy (ordinal rankings of value) it wears out the inferential force of norms and laws.

It is against this backdrop that Thévenot's remarks on the generational 'flouting' of species-genus (syllogistic) reasoning are instructive:

Statistical coding as a scientific activity is ... regulated by logical principles which determine the correct forms of classification. But when a statistician is required to classify [an occupational] post or status which has not already received technical, administrative or legal coding, these logical principles are flouted, and this is the case with young people whose family situations and occupational status are often ill-defined.

(Thévenot 1984:1)

Thévenot explains this as a problem of an 'ill-defined' generation and the flouting of categorical rules. Not as the technical limit of 'correct forms' which infers propositions from the properties of classes. What he does not quite say is that the syllogism deals in absolute all-or-nothing classes, and not the proportionalprobabilistic statements of statistics or the modal logic of possibilities. But no matter.

The point is not that there is an inherent problem with abstraction, numbers or classification as such. This chapter makes no such suggestion. It argues for rethinking operational concepts as something like rough encoding for machine learning let loose through the wild complexity of an eponymous field, rather than 
as necessary forms of knowledge and practice calling upon a managerial investment in the ideal forms of universal standards. It is not, then, that abstraction, imagination or enumeration should be jettisoned for claims of noumenal authenticity, as if this were not already encompassed in the phenomenological form-matter dichotomy. It is that the elementary insistence on 'parts-whole' reasoning of 'correct forms' greets variation, mutability and undecidability with a recurrent, metaphysical question about the ways in which forms of life 'participate' in universal, eternal forms (Welton 2002). It does so, ultimately, as a means of re-affirming a faith in 'the total [idealizable] form encompassing all forms' (Husserl 1970: 35), as the trope of international law, the engineering of organisational systems, or as a more explicit theology of natural law that stakes its ground on the reconstruction of the law of the household. It is a faith that forgets 'that rules and procedures do not actually rule' (Law 2009: 5). But in proceeding from a question of forms (and their scaling and ranking), it glosses over the ineradicable difference between processes and forms, between indefinite processes and objectified classifications. The appeal of the latter draws the emphasis from the processes through which forms are given form, and therefore away from contextual, indefinite questions about infrastructure to the dream of rules that do not rule without violence.

\section{Back to class and the leap beyond classification}

Earlier debates over the use of 'precarity' among radical scholars and movements often turned around the extent to which the neologism could be leveraged around the recomposition and identification of a new class and, moreover, the implications of treating this as a shared ontological circumstance given the material weight of differences between those newly arrived to the experience of, say, zero-hour contracts and those for whom the standard-issue Fordist wage had never been a reality (Vishmidt 2005; Mitropoulos 2005; Gill and Pratt 2008). Since then, others have pointed to the feigning of shared feelings across such divisions that the uptake of concepts such as precarity and precariousness has furnished within and around the university (Gregg 2011). These debates occurred in an institutional context where the standardisation of uncertainty had become an encoded convention of organisational engineering and, moreover, where the social sciences were increasingly being invested by the practices and analytics of risk management. While the Hegelian-Marxist concept of class was imbued with an ahistorical teleology of a universal spirit manifested in imperfect, modal appearances, it can instead be critically understood as the incomplete effect of mundane and methodical processes of classification, including those derived from neoPlatonism. The argument here as to the history of the concepts of précarité and precariousness is that, when those procedures of classification were confronted with their own mathematical, technical limits while, at the same time, there were struggles against the limits of those categorical forms, the statistical categories of GDP and rate of unemployment came to be replaced by sociologists first with a tentative risk-absorption metrics of selective conservation and the law of the 
household and, secondly, by sociologists and government statisticians preoccupied with the flexibility-disorder ratio of précarité. The broader point is that what is being mapped can never be mapped completely.

\section{References}

Aguiar, L. L. M. and Herod, A. (2006) The Dirty Work of Neoliberalism: Cleaners in the Global Economy. Malden, MA: Blackwell.

Ammar, A., Elouedi Z. and Lingras, P. (2015) Semantically segmented clustering based on possibilistic and rough set theories. International Journal of Intelligent Systems 30 (6): 676-706.

Bachelard, G. (1994) The Poetics of Space. Translated by M. Jolas. Massachusetts: Beacon Press.

Barbier, J-C. (2002) A survey of the use of the term Précarite in French economics and sociology. Document de Travail 19. CNRS/Centre d'etudes de l'emploi.

Beck, U. (1992) Risk Society: Towards a New Modernity. London: Sage Publications.

Becker, G. S. (1962) Investment in human capital: A theoretical analysis. Journal of Political Economy 70(5): 9-49.

Benedict, R. (1934) Patterns of Culture. Boston: Houghton Mifflin Company.

Bourdieu, P. (ed.) (1993) La misère du monde. Paris: Éd. du Seuil.

Brown, W. (2005) Edgework: Critical Essays on Knowledge and Politics. Princeton: Princeton University Press.

Butler, J. (2012) Precarious life, vulnerability, and the ethics of cohabitation. The Journal of Speculative Philosophy 26 (2): 134-51.

Clark, G. L. (2000) Pension Fund Capitalism. Oxford: Oxford University Press.

Deleuze, G. and Guattari, F. (1988) A Thousand Plateaus. Trans. Brian Massumi. Minneapolis, MN: University of Minnesota Press.

Desrosières, A. (1998) The Politics of Large Numbers: A History of Statistical Reasoning. Cambridge: Harvard University Press.

Dirac, P. A. M. (2004) The Principles of Quantum Mechanics. Oxford: Clarendon Press.

Elkaisy-Friemuth, M. and Dillon, J. M. (eds) (2009) The Afterlife of the Platonic Soul: Reflections of Platonic Psychology in the Monotheistic Religions. Leiden: Brill.

Eymard-Duvernay, F. (1981) Les secteurs de l'industrie et leurs ouvriers. Économie et statistique 138: 49-68.

French Ministry of Labour (1992) France: First assessment of the 1990 law on precarious employment. European Industrial Relations Review 222: 21-22.

Gill, R.. and Pratt, A. (2008) In the social factory? Immaterial labour, precariousness and cultural work. Theory, Culture \& Society 25(7-8): 1-30.

Gödel, K. (1962) On Formally Undecidable Propositions of Principia Mathematica and Related Systems. New York: Basic Books.

Gugler, J. (1968) The impact of labour migration on society and economy in Sub-Saharan Africa: Empirical findings and theoretical considerations. African Social Research 6: 463-86.

Harley, J. B. (2001) The New Nature of Maps: Essays in the History of Cartography. Baltimore: Johns Hopkins University Press.

Hayek, F. A. (1960) The Constitution of Liberty. Chicago: University of Chicago Press.

Hayek, F. A. (1994) A theory of complex phenomena. In Martin, M. and McIntyre, L. C. (eds), Readings in the Philosophy of Social Science 55-70. Cambridge: MIT Press. 


\section{Angela Mitropoulos}

Hegel, G. W. F. (1977) Phenomenology of Spirit. Translated by Miller, A. V. and Findlay, J. N. Oxford: Clarendon Press.

Herman, E. (2014) Working poverty in the European Union and its main determinants: An empirical analysis. Engineering Economics 25(4): 427-36.

Husserl, E. (1970) The Crisis of European Sciences and Transcendental Phenomenology. An Introduction to Phenomenological Philosophy. Evanston: Northwestern University Press.

International Monetary Fund. (2005) Global Financial Stability Report (April).

International Organization for Standardization (2009) ISO 31000: Risk Management: Principles and Guidelines - Management du risque: Principles et lignes directrices. Geneva: ISO.

Janicaud, D. (2000) Phenomenology and the 'Theological Turn:' The French Debate. New York: Fordham University Press.

Kalecki, M. (1971) Selected Essays on the Dynamics of the Capitalist Economy 19331970. Cambridge: University Press.

Kauffman, S. A. (1991) The sciences of complexity and 'origins of order'. SFI Working Paper: 199104-021. California: Santa Fe Institute.

Kelly, K. A. (2003) Domestic Violence and the Politics of Privacy. Ithaca: Cornell University Press.

Knight, F. H. (2006) Risk, Uncertainty and Profit. Mineola: Dover Publications.

Korzybski, A. (2000) Science and Sanity: An Introduction to Non-Aristotelian Systems and General Semantics. Brooklyn: Institute of General Semantics.

Kowaleski-Jones, L. and Wolfinger, N. H. (2007) Fragile Families and the Marriage Agenda. New York: Springer.

Kuhn, T. S. (1970) The Structure of Scientific Revolutions. Chicago: University of Chicago Press.

Lange, O. (1971) Optimal Decisions: Principles of Programming. New York: Pergamon Press.

Law, J. (2009) The Greer-Bush test: On politics in STS. Heterogeneities.net. Available at: www.heterogeneities.net/publications/Law2009TheGreer-BushTest.pdf (Accessed 3 August 2016).

Lenin, V. I. (1902) What Is to Be Done?: Burning Questions of Our Movement. London: Lawrence.

Luxemburg, R. (2004) The Accumulation of Capital. London: Routledge.

Luxemburg, R. (2006) Leninism or Marxism? In Buhle, P. (ed.) Reform or Revolution and Other Writings. Mineola: Dover.

Macpherson, C. B. (1983) Property: Mainstream and Critical Positions. Toronto: University of Toronto Press.

Manning, E. (2014) Wondering the world directly. Or, how movement outruns the subject. Body \& Society 20(3-4): 162-88.

Masson, A. (1983) Estimation du risque à terme de chômage. Annales de l'Inséé 52: 23-53.

McNeilly, J. (2014) A phenomenology of/with total movement: Response to Erin Manning. Body \& Society 20(3-4): 208-21.

Mériaux, B. (1978) Point de vue sur les recherches françaises en économie du travail. Revue Économique 29 (1): 120-40.

Michon, F., and J. F. Germe (1979) 'Stratégies des entreprises et formes particulières d'emploi' rapport pour le Commissariat Général du Plan. 2. Paris: SET, Université de Paris I. 
Mitropoulos, A. (1999) Discipline and labour: Sociology, class formation and money in Australia at the beginning of the twentieth century. Journal of Sociology 35(1): 77-91.

Mitropoulos, A. (2005) Precari-Us? In Berry-Slater, J. (ed.) The Precarious Reader. London: Mute.

Mitropoulos, A. (2012) Contract and Contagion: From Biopolitics to Oikonomia. Brooklyn: Minor Compositions/Autonomedia.

Mitropoulos, A. (2015) Archipelago of risk: Uncertainty, borders and migration detention systems. New Formations 84: 163-83.

Mitropoulos, A. (2016) Infrastructures of Uncommon Forms. Forthcoming.

Mitropoulos, A. and Bryan, D. (2015) Social benefit bonds: Financial markets inside the state. In Meagher, G. and Goodwin (eds), Markets, Rights and Power in Australian Social Policy. Sydney: Sydney University Press.

Mullally, S. (2015) Care, Migration, and Human Rights: Law and Practice. London: Routledge.

Muntaner, C., H. Chung, Benach, J. and Ng, E. (2012) Hierarchical cluster analysis of labour market regulations and population health: A taxonomy of low- and middleincome countries. BMC Public Health 12(1): 1-15.

O'Rand, A. M. (2011) 2010 SSS Presidential Address: The devolution of risk and the changing life course in the United States. Social Forces 90(1): 1-16.

Piore, M. J. (1978) Dualism in the labor market: A response to uncertainty and flux. The case of France. Revue économique 29(1): 26-48.

Pitrou, A. (1978) La vie précaire des familles face à leurs difficultés. Paris: Caisse nationale des allocations familiales, Caisse nationale des allocations familiales, Laboratoire d'économie et de sociologie du travail.

Pitrou, A. (1992) Les solidarités familiales : vivre sans famille? Toulouse: Privat.

Pleck, E. H. (2004) Domestic Tyranny: The Making of American Social Policy against Family Violence from Colonial Times to the Present. Urbana: University of Illinois Press.

Scherer, S. (2001) Early career patterns: A comparison of Great Britain and West Germany. European Sociological Review 17(2): 119-44.

Schermaier, M. J. (2009) Res Communes Omnium: The history of an idea from Greek philosophy to Grotian jurisprudence Grotiana 30(1): 20-48.

Scott, S. P. (ed.) (1973) The Civil Law, Including the Twelve Tables, the Institutes of Gaius, the Rules of Ulpian, the Opinions of Paulus, the Enactments of Justinian, and the Constitutions of Leo. New York: AMS Press.

Sennett, R. (1999) The Corrosion of Character: The Personal Consequences of Work in the New Capitalism. New York: WW Norton.

Smith, D. K. (2008) The Cartographic Imagination in Early Modern England: Re-Writing the World in Marlowe, Spenser, Raleigh and Marvell. Aldershot: Ashgate.

Stoesz, D. (1999) Unravelling Welfare Reform. Society 36(4): 53-61.

Thévenot, L. (1983a) A propos d'une définition des couches moyennes et de la nouvelle nomenclature des professions et catégories socioprofessionnelles. Revue Française de Sociologie 24(2): 56-79.

Thévenot, L. (1983b) L'économie du codage. Critiques de L'économie Politique 23-24: $188-222$.

Thévenot, L. (1984) Rules and implements: Investment in forms. Social Science Information 23(1): 1-45.

Thévenot, L. (2009) Postscript to the Special Issue: Governing life by standards. Social Studies of Science 39(5): 793-813. 


\section{Angela Mitropoulos}

Verd, J. M. and López-Andreu, M. (2012) La inestabilidad del empleo en las trayectorias laborales. un análisis cuantitativo / Employment Instability in Labour Trajectories. A Quantitative Analysis. Reis 138 (April): 135-48.

Vishmidt, Marina (2005) Precarious straits, in Mute Vol 1, No. 29. The Precarious Issue. Available at: www.metamute.org/editorial/articles/precarious-straits [Accessed 1 December 2016].

Welton, W. A. (ed.) (2002) Plato's Forms: Varieties of Interpretation. Lanham: Lexington Books.

Wood, D. (2010) Rethinking the Power of Maps. New York: Guilford Press. 